\title{
Electron Microscopic Detection of Canine Parvovirus in the Faeces of Dogs
}

\author{
M. Areshkumar*, P. Vijayalakshmi and D. Selvi \\ Department of Veterinary Medicine, Rajiv Gandhi Institute of Veterinary Education and \\ Research, Teaching Veterinary Clinical Campus, Mettupalayam, Puducherry-9, India \\ *Corresponding author
}

\section{A B S T R A C T}

\begin{tabular}{|l|}
\hline K e y w o r d s \\
$\begin{array}{l}\text { Parvovirus, Electron } \\
\text { microscope }\end{array}$ \\
\hline Article Info \\
\hline $\begin{array}{l}\text { Accepted: } \\
\text { 22 April } 2018 \\
\text { Available Online: } \\
\text { 10 May } 2018\end{array}$ \\
\hline
\end{tabular}

\section{Introduction}

Canine parvovirus enteritis (CPE) has become an important problem to dog population worldwide and is diagnosed usually in unvaccinated and seldom in vaccinated puppies. Inadequate immunization to parvovirus during the first year of life is an important risk factor for the disease. Unvaccinated dogs are about 13 times more likely to become infected than vaccinated dogs. Susceptibility of puppies to viral infection increases as the maternally acquired antibody titer declines to non-protective levels.

The age, breed, sex, history and clinical signs and haematological findings of dogs are important in ranking a viral etiology as a likely cause of diarrhoea. Commonly, canine parvovirus (CPV) infects 4-12 week old pups that are prone to acquire the virus in concomitance with the wane of Maternal Derived Antibodies (MDA). Eight weeks is the age when large numbers of puppies succumb to CPV (Marulappa and Sanjay, 2009).

Clinical diagnosis is indecisive and several other viral pathogens may cause diarrhea in dogs, such as corona viruses, adenoviruses, morbilliviruses, rotaviruses and reoviruses, (Greene and Decaro, 2012). Thus, a suspect clinical case should always be confirmed by laboratory tests. The most frequent diagnostic methods for titration of viruses in feces are haemagglutination tests (HA) and enzymelinked immuno sorbent assays (ELISA). CPV 
can be diagnosed by isolation from feces, Polymerase Chain Reaction (PCR), detection by electron microscopy and identification by immune electron microscopy (Dow, 1996; Sherding, 1992).

\section{Identification by electron microscope}

Karasaki (1966), electron microscope and immunofluorescent microscope studies of CPV-infected DKSV (dog kidney SV40 transformed) cells provide strong confirmation that this agent is a parvovirus. Negatively stained particles from purified preparations were 23 to $26 \mathrm{~nm}$ in diameter, which appears to be the characteristic size range of parvoviruses.

Burtonboy et al., (1979) reported that during acute illness, parvoviral virions are readily demonstrated in faeces by negative staining and use of electron microscopy.

\section{Materials and Methods}

In the present study, a total of 98 dogs were presented with hemorrhagic gastroenteritis to Small Animal Medicine Unit of TVCC, RIVER. Faecal samples collected in PBS were subjected for PCR assay.

A total of 53 dogs were diagnosed for canine parvovirus infection by PCR and 5 samples were randomly selected for the electron microscopic study.

The primer pair was $\mathrm{H}_{\text {for }} / \mathrm{H}_{\text {rev }}$ that amplify a large fragment of the capsid protein-encoding gene (VP2) of CPV-2 (Buonavoglia et al., 2001). Primer $\mathrm{H}_{\text {for }}\left(5^{\prime}\right.$ CAG GTG ATG AAT TTG CTA CA3') and $\mathrm{H}_{\text {rev }}$ (5' CAT TTG GAT AAA CTG GTG GT 3'), located at nucleotide position 3556-3575 and 4166-4185 of the CPV genome respectively yield 630bp product (Plate -1).

Plate.1 Agarose gel electrophoresis of PCR product of canine parvovirus

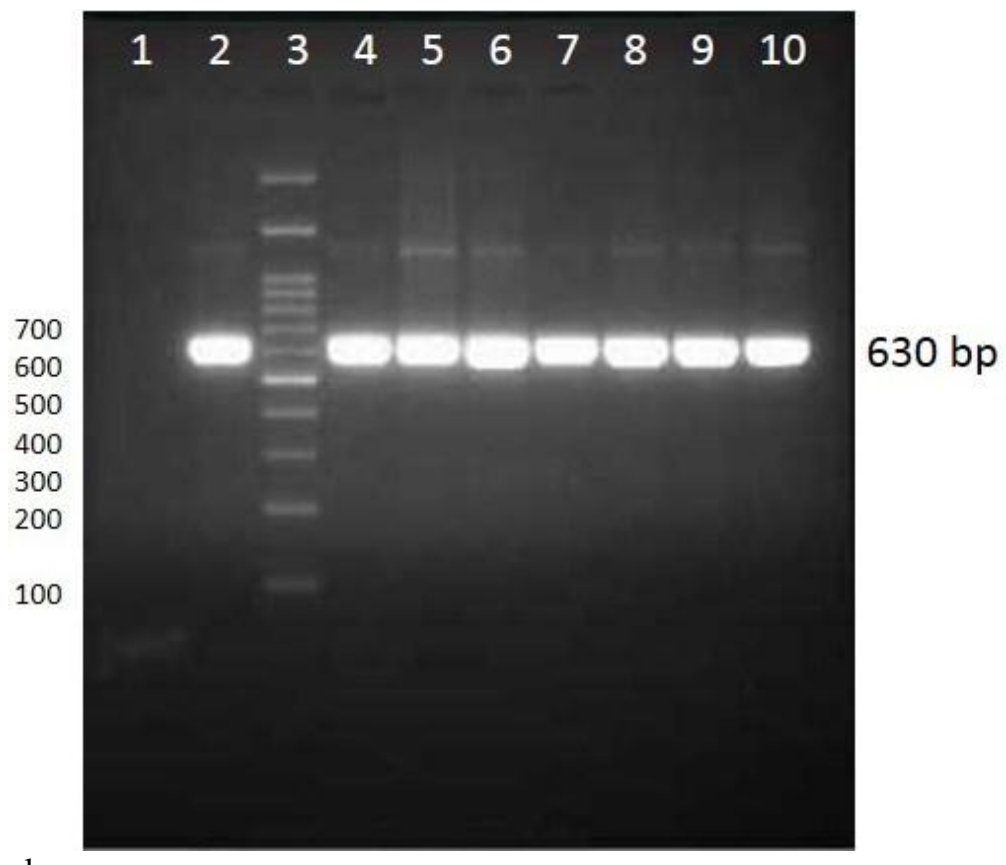

Lane 1: negative control Lane 2: Positive control Lane 3: 100 bp ladder Lane 4-10: positive samples 
Plate.2 Electron micrograph of CPV like virions. Bar marker represents $100 \mathrm{~nm}$

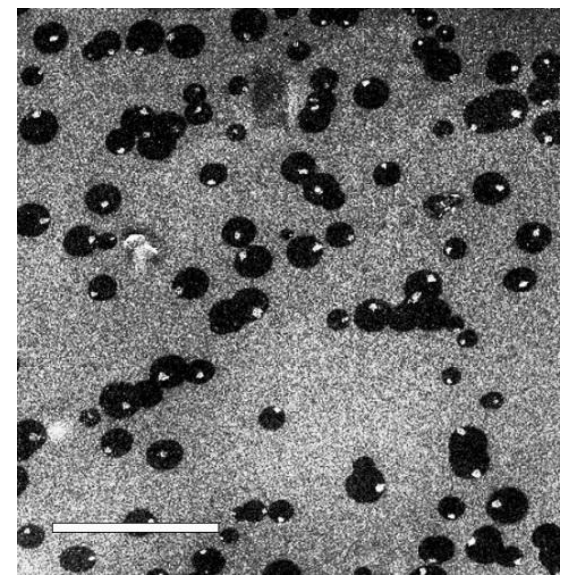

Processing of sample for electron microscopic study was done using the procedure described by Alicia et al., (1999), where $1 \mathrm{ml}$ of each fecal sample was homogenized with $10 \mathrm{ml}$ of phosphate buffered saline (PBS) $\mathrm{pH} 7.2$, and centrifuged at $8,000 \mathrm{rpm}$ during 15 minutes at $4^{\circ} \mathrm{C}$. The sediment was discarded and a second centrifugation at $45,000 \mathrm{rpm}$. for two hours at $4^{\circ} \mathrm{C}$ was performed. The sediment was re-suspended 1:1 with PBS, and one drop was placed on a cooper grid, and allowed to stand one minute. The excess was removed with a piece of filter paper. Two grids were negatively stained with $2 \%$ phosphotungstic acid, pH 7 during 1 minute, and examined with scanning electron microscope (Plate -2).

\section{Results and Discussion}

In the present study all the 5 samples which were subjected for scanning electron microscope showed canine parvo virus like particles under 100nm size (Plate -2). Burtonboy et al., (1979) also reported that during acute illness, parvovirus like virions are readily demonstrated in faeces by negative staining with use of electron microscopy.

The viral detection in faecal suspensions by electron microscopic examination directly confirms the presence of the virus like particles (Mc Adaragh et al., 1979) but this method also presents some drawbacks because the virus may also be detected in the faeces of healthy animals (Azetaka et al., 1981; Danner et al., 1982).

\section{References}

Alicia, N., N. Adriana and A. Miguel (1999). Detection of viral particles in feces of young dogs and their relationship with clinical signs, Revista de Microbiologia, 30:237-241.

Azetaka M., T. Hirasawa, S. Konishi and M. Ogata (1981). Studies on canine parvovirus isolation, experimental infection and serologic survey. Jap. J. Vet. Sci., 43: 243-255.

Buonavoglia C, Martella V, Pratelli A, Tempesta M, Cavalli A. and Buonavoglia D. (2001) Evidence for evolution of canine parvovirus type- 2 in Italy. J Gen Virol; 82:3021-3025.

Burtonboy, G., Coignoul, F., Delferrire, N. and Pastoret, P.P. (1979). Canine hemorrhagic enteriris: detection of viral particles by electron microscopy. Archives. Virol. 61: 1-11.

Danner, K., U. Oldenburg, S. Weber, M. Arens and H. Krauss (1982). Derzeitigeepizootiologische situation beivirusbedingten Enteritiden des Hundes. Prakt. Tierärzt, 6, pp: 512-515. 
Dow, S.W. (1996): Acute medical diseases of the small intestine. In: Tams, T.R. (ed): Handbook of Small Animal Gastroenterology. Ed. W.B. Saunders Company. Philadelphia; pp. 245-266.

Greene, C.E. and Decaro, N. (2012): Canine viral enteritis. In: Greene $\mathrm{CE}$, editor. Infectious diseases of the dog and cat $4^{\text {th }}$ ed. St. Louis: Elsevier; pp. 67-80.

Karasaki, S. (1966). Size and ultrastructure of the $\mathrm{H}$-viruses as determined with the use of specific antibodies. Journal of Ultra structure Research. 16: 109-122

Marulappa, S.Y. and Sanjay kapil (2009): Simple Tests for Rapid Detection of
Canine Parvovirus Antigen and Canine Parvovirus-Specific Antibodies. Clinical and Vaccine Immunology, 16: 127-131.

Mc Adaragh, J.P., D.T. Nelson, S.L. Eustis and I. Stotz (1979). Experimental studies of canine parvovirus: Evaluation of diagnostic procedures. Am. Assoc. Vet. Lab. Diagn., $22^{\text {nd }}$ Annual proceedings, Pp. 405-410.

Sherding, R. (1992). Enfermedades del intestinodelgado. In Ettinger, S.J. (ed.): Tratado de Medicinas Interna Veterinaria. Ed. Intermédica. Bs.As, pp. 1392-1467.

\section{How to cite this article:}

Areshkumar, M., P. Vijayalakshmi and Selvi, D. 2018. Electron Microscopic Detection of Canine Parvovirus in the Faeces of Dogs. Int.J.Curr.Microbiol.App.Sci. 7(05): 3024-3027. doi: https://doi.org/10.20546/ijcmas.2018.705.352 